\title{
Occurrence of Fusarium species and associated T2-toxin in Kenyan wheat
}

\author{
James W. Muthomi ${ }^{1^{*}}$, Scholastica L. Musyimi ${ }^{2}$, John M. Wagacha ${ }^{3}$, Rama D. Narla ${ }^{1}$ \\ ${ }^{1}$ Department of Plant Science and Crop Protection, University of Nairobi, Nairobi, Kenya; \\ *Corresponding Author: james wanjohi@yahoo.com \\ ${ }^{2}$ Ministry of Agriculture, Nairobi, Kenya \\ ${ }^{3}$ Department of Biological Sciences, University of Nairobi, Nairobi, Kenya
}

Received 9 October 2011; revised 16 November 2011; accepted 14 December 2011

\section{ABSTRACT}

Survey covering 120 wheat fields was conducted in three wheat-growing districts of Kenya during the 2008 cropping season to determine the incidence of Fusarium head blight (FHB) and T2-toxin contamination in grain. FHB incidence was determined as the number of blighted ears per $10 \mathrm{~m}^{2}$. Information gathered included wheat production practices, rainfall and temperature data. Fungal pathogens were isolated from wheat stems, heads, straw, grains and soil and identified based on cultural and morphological characteristics. Wheat grain samples were analyzed for T2-toxin by competitive Enzyme Linked Immunosorbent Assay (ELISA). High FHB incidences of up to $88 \%$ were recorded. Fungal genera isolated included Fusarium, Epicoccum, Trichoderma, Alternaria and Penicilium. Wheat plant parts with high infection with Alternaria and Epicoccum had corresponding low levels of Fusarium spp. Whereas Fusarium spp. were the most common fungal pathogens in stems, heads and soil, Epicoccum was frequently isolated from straw and grains. Fusarium speciesisolated included F. poae, F. graminearum, F. stilboides, F. verticilloides, F. fusarioides, F. tricinctum and $F$. heterosporum with $F$. poae and $F$. graminearum accounting for approximately $40 \%$ of all Fusarium infections. T2-toxin was detected in all the grain samples and varied from 3 to $22 \mathrm{ppb}$. The study showed that FHB and T2toxin are prevalent in the study districts and the high diversity of Fusarium species implies a challenge in FHB management as well as a risk of chronic T2-toxin exposure to humans and livestock.

Keywords: Fusarium; Head Blight; Mycotoxins; T2-
Toxin; Trichothecenes; Wheat

\section{INTRODUCTION}

Wheat (Triticum aestivum L.) is the second most important cereal grain in Kenya after maize [1]. Fusarium head blight (FHB) or scab of wheat and barley is mainly caused by a complex of the soil- and residue-borne Fusarium spp. which also cause foot rot and root rot $[2,3]$. However, F. graminearum, F. culmorum, F. poae and F. avenaceum predominate depending on climatic conditions [4]. The disease is one of the most destructive in areas characterized by warm and humid weather especially after heading of wheat [5]. It reduces grain yield due to grain shriveling and quality due to production of mycotoxins which adversely affect human and livestock productivity and health. The major mycotoxins associated with Fusarium spp. include deoxynivalenol, nivalenol, T2-toxin, zearalenone and their derivatives [6]. Majority of wheat growers in Kenya are small-scale farmers with less than 20 acres [7,8]. Most of these producers do not use fungicides for fungal disease management. Additionally, maize, which is the country's staple food and known to promote FHB incidence and severity is grown either side-by-side or as a rotation crop with wheat $[8,9]$.

Wheat can be infected by Fusarium spp. during all growth stages, although anthesis is the most susceptible developmental stage. Rainfall during this stage often results in economically important FHB infections. Genetic variation and climatic factors result in differences in mycotoxins produced by Fusarium spp. [10]. Earlier studies conducted in Nyandarua and Nakuru districts of Kenya showed that different fungal genera and Fusarium spp. were isolated from wheat kernels $[9,11,12]$. Additionally, aflatoxins, deoxynivalenol, nivalenol and T2toxin were detected in wheat grains from these studies. However, most of the previous studies in the country assessed infection of the grains and not vegetative parts 
and straw after harvest. Vegetative wheat parts and wheat debris play a critical role in the survival of Fusarium spp. thereby acting as the source of primary inoculum for a new crop [13]. Straw may also be a pathway of introduction of mycotoxins to livestock feed chain. This study was therefore carried out to determine FHB inoculum levels in stems, heads, grains, straw and soil sampled from major wheat growing districts of Kenya as well as T2-toxin contamination of wheat grain.

\section{MATERIALS AND METHODS}

\subsection{Field Sampling and FHB Incidence Assessment}

A field survey was carried out between July and November 2008 before and after wheat harvesting, in 12 agro-ecological zones (AEZ; Table 1) of major wheat growing districts of Narok, Imenti North and Nyandarua North in Kenya. The AEZ included upper highland 2, 3 and 4 as well as lower highland 2, 3 and 4 distributed among the three districts. Ten farms, both large and small scale, were randomly sampled in each AEZ by selecting the fifth wheat-growing farm in a transect such that a total of 120 farms were surveyed. A semi-structured questionnaire was used to obtain production information such as cultivars grown, crops cultivated, and pest and disease management practices.

Fusarium Head Blight incidence was determined as the proportion of diseased heads within four $10 \mathrm{M}^{2}$ randomly selected quadrants in each farm. Half a kilo of fresh stem bases and blighted wheat heads were randomly sampled per field before harvesting (GS87). At harvest, approximately $1 \mathrm{~kg}$ of freshly harvested kernels and straw were collected in khaki paper bags for mycological and mycotoxin analysis. Top soil was collected from 5 different points of each farm, mixed to make a single sample from which a $1 \mathrm{~kg}$ sub-sample was taken for fungal isolation. Stems, straw and immature wheat heads were sampled only in Nyandarua North and Imenti North districts. All samples were stored at $4^{\circ} \mathrm{C}$ until analyzed.

\subsection{Microbiological Assays}

Half a centimeter long stems, heads and straw as well as kernels were surface sterilized in 3\% sodium hypochlorite with 3 drops of Tween 20 for three minutes and subsequently rinsed thrice for two minutes in sterile distilled water. The sections were then plated on low strength potato dextrose agar modified with salts and antibiotics [14]. Ten pieces of wheat stems, heads and straw were plated per Petri dish and replicated 5 times. However, the sample size for the kernels per field was 100 and therefore replicated 10 times. Isolation from soil samples was done by dissolving $1 \mathrm{~g}$ of the sample in 9 $\mathrm{mL}$ of sterile distilled water which was serially diluted up to $10^{-6}$. One milliliter of the $10^{-4}$ and $10^{-5}$ dilutions of each sample were plated on PDA and evenly dispersing the suspension at the bottom of sterile Petri dishes. Ten milliliters of molten PDA amended with 40 ppm of antibiotics was then added in each Petri dish. The plates were incubated for $5-7$ days at $25^{\circ} \mathrm{C}$ under $12 \mathrm{~h}$ daylight and $12 \mathrm{~h}$ darkness cycles. Counts were made of the total number of infected seeds or pieces of wheat material per plate.

Different fungal genera and Fusarium species colonies per Petri dish were counted for soil samples and the number of colony forming units per gram (CFU/g) calculated by multiplying the number of colonies by dilution factor for the soil. Fusarium colonies were sub-cultured on PDA and synthetic nutrient agar (SNA) [15]. Cultures on SNA were incubated under near UV-light to facilitate sporulation while those on PDA were incubated at $25^{\circ} \mathrm{C}$ for $14-21$ days. Fusarium species were identified based on morphological and cultural characteristics [16-18]. Other fungal genera were sub-cultured on PDA and identified to genus level based on cultural and morphological characteristics.

\subsection{T2-Toxin Analysis}

T2-toxin in wheat grains was analyzed by direct competitive Enzyme-Linked Immunosorbent Assay (ELISA) $[19,20]$. Each sample was homogenized and $100 \mathrm{~g}$ sub-

Table 1. Characteristics of different agro ecological zones (AEZ) in wheat growing districts, Kenya covered during the field monitoring.

\begin{tabular}{cccc}
\hline AEZ & Description & Annual mean rainfall (mm) & Length of growing period (days) \\
\hline Lower Highland 3 (LH3) & Wheat-maize-barley zone & $750-900$ & $190-260$ \\
Lower Highland 4 (LH4) & Cattle-sheep-barley zone & $700-1400$ & $115-130$ \\
Lower Highland 2 (LH2) & Wheat-maize-pyrethrum zone & $1200-1800$ & $320-340$ \\
Upper Highland 3 (UH3) & Upper wheat-barley zone & $700-1000$ & $280-300$ \\
Upper Highland 4 (UH4) & Maize-wheat zone & $600-850$ & $230-280$ \\
\hline
\end{tabular}

Source: Ministry of agriculture and GTZ [46]. 
sample ground to fine powder. Five grams of the ground sample was extracted with $25 \mathrm{~mL}$ of methanol: water $(70 / 30 \mathrm{v} / \mathrm{v})$ for T2-toxin. The extract was de-fatted with $10 \mathrm{~mL}$ hexane, and $4 \mathrm{~mL}$ of the methanolic layer was diluted to $10 \%$ using phosphate buffer solution. The methanolic extract was diluted with an equal volume of distilled water. A commercial kit (Ridascreen, r-Biopharm, Germany) was used and the ELISA procedure performed following the manufacturer's recommendations. Absorbance was determined using the spectrophotometer ELISA reader (Uniskan II, Finland) at $450 \mathrm{~nm}$. A calibration curve for the standards for each toxin dilution was plotted using log 10 of standards concentration against the percentage inhibition of the standards.

\subsection{Data Analysis}

Survey data was analyzed using statistical package for social sciences version 12 for windows (SPSS). All other data were subjected to analysis of variance (ANOVA) using the PROC ANOVA procedure of Genstat, VSN International limited, 2008 edition III. Differences among the treatment means were separated using the Fisher's protected LSD test at 5\% probability level. Where necessary data was transformed using square root applying the formula; = SQT $(\mathrm{n}+0.5)$ where $\mathrm{n}$ was the number of observations and SQT was square root and 0.5 was a constant.

\section{RESULTS}

\subsection{Wheat Production Practices}

Data on the production systems provided information on their possible contribution to build-up of Fusarium inoculum in the three wheat growing regions (Table 2). A total of 14 wheat varieties were cultivated in the three districts. Newer released varieties were more popular with the farmers compared to the older ones. Majority (71\%) of the farmers either rotated wheat with maize or grew the two crops side by side. Only $15 \%$ of the farmers grew wheat in a monoculture system although no farmer in Imenti North district cultivated wheat as a sole crop. Aphids (73\%) and stem rust $(77 \%)$ were the most important pest and disease, respectively in the three districts.

\subsection{Fungal Inoculum in Wheat Stems}

The fungal genera commonly isolated from wheat stems were Fusarium, Alternaria and Epicoccum (Table 3). However, there was variability in the predominance of fungal genera between the districts and among the AEZ. For example, whereas Fusarium spp. were predominant $(57 \%)$ in Imenti north district, Epicoccum was predominant $(48 \%)$ in Nyandarua North district. Where Fusarium spp. were isolated in high frequency, Alternaria and Epicoccum were isolated in low frequency and vice versa.

Table 2. Characteristics of wheat production systems in the study districts of Kenya covered during the field survey.

\begin{tabular}{|c|c|c|c|c|c|c|c|}
\hline \multicolumn{2}{|c|}{ Varieties } & \multicolumn{2}{|c|}{ Other cultivated crops } & \multicolumn{2}{|c|}{ Insects \& diseases } & \multicolumn{2}{|c|}{ Insecticides \& fungicides } \\
\hline Njoro BW II & 45.0 & Maize & 70.8 & Aphids & 72.5 & Dimethoate $^{\circledR}$ & 43.3 \\
\hline Kwale & 25.0 & Beans & 36.7 & Army worms & 10.0 & Bactril $^{\mathbb{R}}$ & 5.8 \\
\hline Duma & 14.2 & Peas & 31.7 & Cut worms & 6.7 & Bestox $^{\circledR}$ & 6.7 \\
\hline Njoro BW I & 5.0 & None & 15.0 & Boll worms & 1.7 & Neural $D^{\circledR}$ & 3.3 \\
\hline Heroe & 3.3 & Cabbage & 14.7 & Other insects & 18.3 & Ogor $^{\circledR}$ & 6.7 \\
\hline Popo & 2.5 & Carrots & 7.5 & Stem rust & 76.7 & Cyclone $^{\circledR}$ & 3.3 \\
\hline Kongoni & 1.7 & Kales & 6.7 & Yellow rust & 15.0 & Karate $^{\circledR}$ & 3.3 \\
\hline Mbuni & 1.7 & Onions & 3.3 & Blight & 4.2 & Other insecticides & 31.0 \\
\hline Mamba & 1.7 & & & Smut & 6.7 & Folicur $^{\circledR}$ & 75.8 \\
\hline Chiriku & 1.7 & & & Wilt & 5.0 & Tilt $^{\circledR}$ & 10.0 \\
\hline Local varieties & 0.8 & & & Other diseases & 8.3 & Silvacur $^{\circledR}$ & 3.3 \\
\hline Bounty & 0.8 & & & & & Thiovit $^{\circledR}$ & 2.5 \\
\hline Chuzi & 0.8 & & & & & Pearl $^{\circledR}$ & 1.7 \\
\hline Not known & 13.3 & & & & & Other fungicides & 21.7 \\
\hline
\end{tabular}


Table 3. Frequency (\%) of fungal genera isolated from wheat stems sampled in two wheat growing districts of Kenya.

\begin{tabular}{|c|c|c|c|c|c|c|}
\hline \multirow{2}{*}{ A. Fungal genera } & \multicolumn{3}{|c|}{ Imenti North } & \multicolumn{3}{|c|}{ Nyandarua North } \\
\hline & LH2 & LH4 & Mean & LH3 & LH4 & Mean \\
\hline Fusarium & 57.1 & 57.6 & 57.3 & 23.6 & 31.8 & 27.7 \\
\hline Alternaria & 27.8 & 26.2 & 27.0 & 49.0 & 19.4 & 34.2 \\
\hline Epicoccum & 15.2 & 16.3 & 15.7 & 27.5 & 48.9 & 38.2 \\
\hline \multicolumn{7}{|l|}{ B. Fusarium spp. } \\
\hline F. poae & 16.9 & 16.4 & 16.7 & 11.7 & 12.2 & 12.1 \\
\hline F. graminearum & 8.2 & 10.4 & 9.3 & 13.5 & 13.0 & 13.2 \\
\hline F. verticilloides & 11.5 & 11.1 & 11.3 & 5.7 & 9.8 & 9.4 \\
\hline F. tricinctum & 8.7 & 8.2 & 8.5 & 6.1 & 7.6 & 7.4 \\
\hline F. fusariodes & 7.3 & 6.6 & 6.9 & 7.0 & 7.3 & 7.3 \\
\hline F. stilboides & 6.6 & 6.6 & 6.6 & 6.4 & 6.7 & 6.7 \\
\hline F. heterosporum & 6.5 & 6.4 & 6.5 & 6.4 & 6.7 & 6.7 \\
\hline
\end{tabular}

LH4: Lower highland; LH3: Lower highland 3; LH2: Lower highland 2.

There were no significant $(\mathrm{p}<0.05)$ differences in isolation frequency of the fungal genera among the AEZ. The Fusarium species isolated from wheat stems were $F$. graminearum, F. poae, F. heterosporum, F. fusariodes, F. tricinctum, F. stilboides and F. verticillioides (Table 3). Fusarium poae and F. graminearum accounted for $40 \%$ of all Fusarium infections and there was inverse proportion in isolation frequency of F. poae and F. graminearum in the AEZ and districts. However, the isolation frequency of the different Fusarium spp. was not significantly $(\mathrm{p}<0.05)$ different among the AEZ and districts.

\subsection{Fusarium Head Blight Incidence and Fungal Species Infecting Immature Heads and Straw at Harvest}

The proportion of blighted heads per $10 \mathrm{M}^{2}$ varied from $68 \%$ to $88 \%$ (Table 4 ). However, there were no significant $(p<0.05)$ differences in disease incidence among the AEZ and districts. In both districts, Fusarium spp. were isolated in high frequency from samples taken from fields and AEZ where FHB incidence was high. Fusarium, Epicoccum, Alternaria and Penicillium were the frequently isolated fungal genera from immature wheat heads, with Fusarium having the highest isolation frequency of up to $54.2 \%$ while Penicillium was the least frequently isolated at $2.7 \%$ (Table 4 ). There were no significant $(p<0.05)$ differences in the isolation frequency of any of the fungal genera among the AEZ. Similar spectrum of Fusarium species was isolated from immature wheat heads and stems (Table 4). The isolation frequency of Fusarium spp. in decreasing order was $F$. graminearum, F. poae, F. verticillioides, F. tricinctum, $F$. stilboides, F. fusarioides and F. heterosporum. There were no significant $(\mathrm{p}<0.05)$ differences in the isolation frequency of Fusarium spp. from immature wheat heads among the AEZ.

Three fungal genera, Fusarium, Epicoccum, and Alternaria, were isolated from wheat straw at harvest (Table 5). There were no significant $(\mathrm{p}<0.05)$ differences in the isolation frequency of the fungal genera among the AEZ in the two districts indicating similar level of fungal contamination in the different agro-climatic regions. Fusarium poae and F. graminearum were the predominant species infecting straw while the proportion of other Fusarium species was negligible.

\subsection{Diversity and Frequency of Fungal Species Isolated from Soil}

Fusarium, Trichoderma, Alternaria, Epicoccum and Penicilium were common in all the soil samples although their frequency of isolation varied in different agro-ecological zones (Table 6). However, there were no significant $(\mathrm{p}<0.05)$ differences in the number of colony forming units of individual fungal genera isolated from different AEZ within the same district. Fusarium poae and F. graminearum were the most common Fusarium spp. in soil, forming up to $69.7 \times 10^{4} \mathrm{CFU} / \mathrm{g}$ and $7.0 \times$ $10^{4} \mathrm{CFU} / \mathrm{g}$, respectively (Figure 1). However, there were no significant $(\mathrm{p}<0.05)$ differences in the isolation frequency of the two species among the AEZ and districts. 
Table 4. Isolation frequency (\%) of fungi contaminating wheat heads and FHB incidence (\%) in two wheat growing districts in Kenya.

\begin{tabular}{|c|c|c|c|c|c|c|}
\hline \multirow{2}{*}{ A. Fungal genera ${ }^{1}$} & \multicolumn{3}{|c|}{ Imenti North } & \multicolumn{3}{|c|}{ Nyandarua North } \\
\hline & LH2 & LH4 & Mean & LH3 & LH4 & Mean \\
\hline Fusarium & 58.0 & 50.1 & 54.1 & 71.6 & 37.0 & 54.3 \\
\hline Epicoccum & 25.0 & 21.7 & 23.4 & 8.5 & 45.8 & 27.2 \\
\hline Alternaria & 15.5 & 18.8 & 17.2 & 19.9 & 17.2 & 18.6 \\
\hline Penicillium & 1.5 & 9.3 & 5.4 & 0.0 & 0.0 & 0.0 \\
\hline \multicolumn{7}{|l|}{ B. Fusarium spp. ${ }^{1}$} \\
\hline F. graminearum & 10.8 & 10.8 & 10.8 & 13.5 & 11.8 & 12.7 \\
\hline F. poae & 13.0 & 8.6 & 10.8 & 13.1 & 10.9 & 12.0 \\
\hline F. verticilloides & 10.9 & 12.2 & 11.5 & 11.6 & 8.7 & 10.1 \\
\hline F. tricinctum & 9.2 & 9.8 & 9.5 & 9.2 & 7.8 & 8.5 \\
\hline F. stilboides & 9.7 & 7.8 & 8.5 & 6.9 & 7.1 & 7.0 \\
\hline F. fusariodes & 7.2 & 7.7 & 7.5 & 8.0 & 7.3 & 7.6 \\
\hline F. heterosporum & 6.4 & 7.8 & 7.1 & 6.5 & 6.7 & 6.6 \\
\hline C. FHB incidence (\%) & 81.4 & 67.7 & 74.5 & 87.5 & 82.3 & 84.9 \\
\hline
\end{tabular}

${ }^{1}$ No significant difference in isolation frequency of the fungal pathogens among the AEZ; LH4: Lower highland; LH3: Lower highland 3; LH2: Lower highland 2.

Table 5. Isolation frequency (\%) of fungal pathogens infecting wheat straw in different agro-ecological zones at harvest.

\begin{tabular}{|c|c|c|c|c|c|}
\hline \multirow{3}{*}{ District } & \multirow{3}{*}{ AEZ } & \multicolumn{4}{|c|}{ Frequency (\%) of fungal pathogens ${ }^{1}$} \\
\hline & & \multirow{2}{*}{ Alternaria spp. } & \multirow{2}{*}{ Epicoccum spp. } & \multicolumn{2}{|c|}{ Fusarium spp. } \\
\hline & & & & F. poae & F. graminearum \\
\hline \multirow[t]{2}{*}{ Nyandarua } & LH3 & 20.2 & 26.0 & 28.7 & 24.9 \\
\hline & LH4 & 18.4 & 26.2 & 31.9 & 24.0 \\
\hline \multirow{3}{*}{ North } & UH3 & 19.5 & 28.0 & 24.9 & 27.3 \\
\hline & UH4 & 18.2 & 28.7 & 28.4 & 24.6 \\
\hline & Mean & 19.1 & 27.2 & 28.4 & 25.2 \\
\hline \multirow{5}{*}{ Narok } & LH4 & 25.9 & 33.5 & 27.4 & 13.2 \\
\hline & UH2 & 23.9 & 32.3 & 29.4 & 15.2 \\
\hline & UH3 & 23.7 & 33.7 & 26.9 & 16.0 \\
\hline & UH4 & 25.4 & 32.2 & 28.4 & 13.6 \\
\hline & Mean & 24.7 & 32.9 & 28.0 & 14.5 \\
\hline
\end{tabular}

${ }^{1}$ No significant difference in isolation frequency of the fungal pathogens among the AEZ; LH4: Lower highland; LH3: Lower highland 3; LH2: Lower highland 2; UH3: Upper highland 3; UH4: Upper highland 4.

\subsection{Diversity and Frequency of Fungal Species Isolated from Wheat Kernels}

Similar spectrum of fungal genera was isolated from wheat kernels as from soils sampled from wheat fields (Table 7). Epicoccum spp. was the most prevalent genera in wheat kernels sampled from Nyandarua North and Narok districts while in Imenti, Alternaria was the most common. In AEZ where Epicoccum and Alternaria were isolated in high frequency, Fusarium was less common. There were significant $(\mathrm{p}<0.05)$ differences in isolation frequency of individual fungal genera among the AEZ. A 


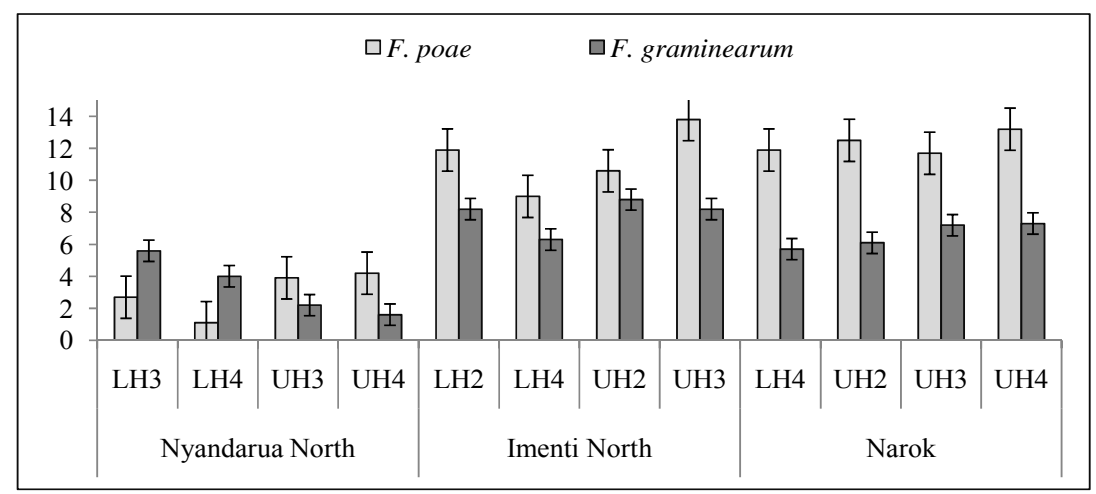

Figure 1. Isolation frequency $\left(\mathrm{CFU} \cdot \mathrm{g}^{-1}\right)$ of $F$. poae and F. graminearum isolated from soil sampled from wheat fields in different agro-ecological zones of wheat growing districts in Kenya. LH4: Lower highland 4, UH2: Upper highland 2; UH3: Upper highland 3; UH4: Upper highland 4; LH3: Lower highland 3; LH2: Lower highland 2; Data transformed using formula $=$ Square root $(\mathrm{CFU}+0.5)$.

Table 6. Fungal genera (CFU/g) isolated from soil in different agro-ecological zones of wheat growing districts in Kenya.

\begin{tabular}{|c|c|c|c|c|c|c|}
\hline \multirow{2}{*}{ District } & \multirow{2}{*}{$\mathrm{AEZ}^{\mathrm{a}}$} & \multicolumn{5}{|c|}{ Colony forming units (CFU/g) of fungal pathogens } \\
\hline & & Fusarium $^{\mathrm{b}}$ & Alternaria & Trichoderma & Epicoccum & Penicillium \\
\hline \multirow[t]{2}{*}{ Nyandarua } & LH3 & 14.9 & 10.2 & 8.7 & 10.8 & 10.4 \\
\hline & LH4 & 15.6 & 11.0 & 7.8 & 8.9 & 8.6 \\
\hline \multirow{3}{*}{ North } & UH3 & 16.5 & 10.1 & 7.7 & 7.2 & 6.7 \\
\hline & UH4 & 6.8 & 8.4 & 4.6 & 5.8 & 4.7 \\
\hline & Mean & 13.5 & 9.9 & 7.2 & 8.2 & 7.6 \\
\hline \multirow[t]{2}{*}{ Imenti } & LH2 & 14.1 & 12.8 & 12.9 & 5.6 & 9.4 \\
\hline & LH4 & 11.5 & 12.6 & 13.0 & 7.7 & 9.5 \\
\hline \multirow{3}{*}{ North } & UH2 & 13.8 & 13.3 & 12.0 & 8.5 & 9.5 \\
\hline & UH3 & 16.3 & 14.8 & 12.3 & 9.8 & 11.0 \\
\hline & Mean & 13.9 & 13.4 & 12.6 & 7.9 & 9.9 \\
\hline \multirow{5}{*}{ Narok } & LH4 & 14.0 & 17.5 & 11.8 & 14.1 & 13.5 \\
\hline & UH2 & 13.2 & 15.5 & 10.4 & 9.8 & 11.4 \\
\hline & UH3 & 13.4 & 13.2 & 6.5 & 8.9 & 8.2 \\
\hline & UH4 & 14.7 & 16.3 & 13.7 & 12.7 & 13.5 \\
\hline & Mean & 13.8 & 15.6 & 10.6 & 11.4 & 11.7 \\
\hline
\end{tabular}

${ }^{\mathrm{a}}$ No significant difference $(\mathrm{p}<0.05)$ among the AEZ within the districts for each pathogen; ${ }^{\mathrm{b}} \mathrm{F}$. poae and F. graminearum were the common species in the different AEZ in the three districts; LH4: Lower highland 4, UH2: Upper highland 2; UH3: Upper highland 3; UH4: Upper highland 4; LH3: Lower highland 3; $\mathrm{LH} 2$. Data transformed using formula $=$ Square $\operatorname{root}(\mathrm{CFU}+0.5)$.

total of seven Fusarium spp., F. poae, F. graminearum, F. fusarioides, F. stilboides, F. verticillioides, F. heterosporum and $F$. tricinctum, were isolated from wheat kernels at harvest (Table 8). The prevalence of Fusarium infection on field basis was $100 \%$. Fusarium poae was the most common species in Nyandarua North and Imenti
North districts while $F$. fusarioides was predominant in Narok district. Overall, F. poae and F. graminearum were the most common species in all AEZ accounting for $40 \%$ of all Fusarium infections of the kernels. The highest and lowest isolation rates of $F$. poae were in AEZ UH4 (17.4\%) and AEZ UH3 (11\%), respectively. 
Table 7. Isolation frequency (\%) of fungal genera contaminating wheat kernels from different agro-ecological zones of wheat growing districts at harvest.

\begin{tabular}{|c|c|c|c|c|c|c|}
\hline District & $\mathrm{AEZ}^{\mathrm{a}}$ & Fusarium & Alternaria & Trichoderma & Epicoccum & Penicillium \\
\hline \multirow[t]{3}{*}{ Nyandarua } & LH3 & $28.5 \mathrm{~b}$ & $13.0 \mathrm{a}$ & $10.7 \mathrm{a}$ & $37.3 \mathrm{a}$ & $10.4 \mathrm{a}$ \\
\hline & LH4 & $29.9 \mathrm{a}$ & $15.9 \mathrm{a}$ & $10.3 \mathrm{a}$ & $33.5 b$ & $10.4 \mathrm{a}$ \\
\hline & UH3 & $28.5 \mathrm{~b}$ & $13.0 \mathrm{a}$ & $10.6 \mathrm{a}$ & $37.5 b$ & $10.5 \mathrm{a}$ \\
\hline \multirow{2}{*}{ North } & UH4 & $29.4 \mathrm{a}$ & $15.8 \mathrm{a}$ & $11.1 \mathrm{a}$ & $33.5 \mathrm{a}$ & $10.2 \mathrm{a}$ \\
\hline & Mean & 29.1 & 14.4 & 10.7 & 35.5 & 10.4 \\
\hline \multirow[t]{2}{*}{ Imenti } & LH2 & $24.6 \mathrm{a}$ & $26.1 \mathrm{c}$ & $11.0 \mathrm{a}$ & $21.3 \mathrm{c}$ & $17.0 \mathrm{~b}$ \\
\hline & LH4 & $19.3 \mathrm{c}$ & $31.0 \mathrm{a}$ & $10.1 \mathrm{a}$ & $21.6 \mathrm{c}$ & $18.0 \mathrm{a}$ \\
\hline \multirow{5}{*}{ North } & $\mathrm{UH} 2$ & $20.0 \mathrm{~b}$ & $29.1 \mathrm{~b}$ & $11.7 \mathrm{a}$ & $28.0 \mathrm{a}$ & $11.2 \mathrm{c}$ \\
\hline & UH3 & $21.1 \mathrm{~b}$ & $29.3 \mathrm{~b}$ & $11.7 \mathrm{a}$ & $26.1 \mathrm{~b}$ & $11.8 \mathrm{c}$ \\
\hline & Mean & 21.3 & 28.9 & 11.1 & 24.3 & 14.5 \\
\hline & LH4 & $21.0 \mathrm{~b}$ & $20.6 \mathrm{~b}$ & $12.5 \mathrm{a}$ & $31.2 \mathrm{c}$ & $14.7 \mathrm{a}$ \\
\hline & $\mathrm{UH} 2$ & $14.8 \mathrm{c}$ & $19.4 \mathrm{c}$ & $12.1 \mathrm{a}$ & $41.5 \mathrm{~b}$ & $12.2 \mathrm{c}$ \\
\hline \multirow[t]{3}{*}{ Narok } & UH3 & $14.9 \mathrm{c}$ & $18.0 \mathrm{~d}$ & $12.2 \mathrm{a}$ & $43.0 \mathrm{a}$ & $12.0 \mathrm{c}$ \\
\hline & $\mathrm{UH} 4$ & $31.5 \mathrm{a}$ & $24.7 \mathrm{a}$ & $11.7 \mathrm{a}$ & $19.1 \mathrm{~d}$ & $13.0 \mathrm{~b}$ \\
\hline & Mean & 20.6 & 20.7 & 12.1 & 33.7 & 13.0 \\
\hline
\end{tabular}

Means followed by different letters within the columns are significantly $(\mathrm{p}<0.05)$ different; LH4: Lower highland 4, UH2: Upper highland 2; UH3: Upper highland 3; UH4: Upper highland 4; LH3: Lower highland 3; LH2: Lower highland 2.

Table 8. Isolation frequency (\%) of Fusarium spp. contaminating wheat kernels in different agro-ecological zones of three wheat growing districts at harvest.

\begin{tabular}{|c|c|c|c|c|c|c|c|c|}
\hline District & $A E Z$ & F. poae & F. gram & F. fusa & F. stil & F. vert & F. hete & F. tric \\
\hline Nyandarua & LH3 & $12.6 \mathrm{a}$ & $12.1 \mathrm{a}$ & $6.4 \mathrm{a}$ & $6.4 \mathrm{a}$ & $6.4 \mathrm{a}$ & $6.4 \mathrm{a}$ & $6.4 \mathrm{a}$ \\
\hline \multirow{4}{*}{ North } & LH4 & $12.5 \mathrm{a}$ & $12.1 \mathrm{a}$ & $6.5 \mathrm{a}$ & $6.3 \mathrm{a}$ & $6.8 \mathrm{a}$ & $6.4 \mathrm{a}$ & $6.5 \mathrm{a}$ \\
\hline & UH3 & $11.5 \mathrm{a}$ & $12.9 \mathrm{a}$ & $6.4 \mathrm{a}$ & $6.4 \mathrm{a}$ & $6.4 \mathrm{a}$ & $6.4 \mathrm{a}$ & $6.4 \mathrm{a}$ \\
\hline & UH4 & $12.8 \mathrm{a}$ & $12.2 \mathrm{a}$ & $6.3 \mathrm{a}$ & $6.3 \mathrm{a}$ & $6.5 \mathrm{a}$ & $6.3 \mathrm{a}$ & $6.4 \mathrm{a}$ \\
\hline & Mean & 12.4 & 12.3 & 6.4 & 6.3 & 6.5 & 6.4 & 6.4 \\
\hline \multirow[t]{3}{*}{ Imenti } & LH2 & $17.1 \mathrm{a}$ & $7.3 \mathrm{a}$ & $6.2 \mathrm{a}$ & $6.2 \mathrm{a}$ & $8.3 \mathrm{a}$ & $6.2 \mathrm{a}$ & $6.2 \mathrm{a}$ \\
\hline & LH4 & $12.1 \mathrm{~d}$ & $7.5 \mathrm{a}$ & $6.2 \mathrm{a}$ & $6.2 \mathrm{a}$ & $6.2 \mathrm{c}$ & $6.6 \mathrm{a}$ & $6.2 \mathrm{a}$ \\
\hline & $\mathrm{UH} 2$ & $14.9 \mathrm{c}$ & $7.9 \mathrm{a}$ & $6.3 \mathrm{a}$ & $6.3 \mathrm{a}$ & $6.6 \mathrm{~b}$ & $6.3 \mathrm{a}$ & $6.3 \mathrm{a}$ \\
\hline \multirow{4}{*}{ North } & UH3 & $15.3 \mathrm{~b}$ & $9.0 \mathrm{a}$ & $6.3 \mathrm{a}$ & $6.4 \mathrm{a}$ & $6.7 \mathrm{~b}$ & $6.4 \mathrm{a}$ & $6.5 \mathrm{a}$ \\
\hline & Mean & 14.9 & 7.9 & 6.3 & 6.3 & 6.9 & 6.4 & 6.3 \\
\hline & LH4 & $13.0 \mathrm{c}$ & $7.7 \mathrm{~b}$ & $6.5 \mathrm{a}$ & $6.4 \mathrm{a}$ & $8.4 \mathrm{~b}$ & $6.4 \mathrm{~b}$ & $7.19 \mathrm{a}$ \\
\hline & $\mathrm{UH} 2$ & $16.2 \mathrm{~b}$ & $9.5 \mathrm{a}$ & $6.3 \mathrm{a}$ & $6.3 \mathrm{a}$ & $6.7 \mathrm{c}$ & $6.3 b$ & $6.33 \mathrm{a}$ \\
\hline \multirow[t]{3}{*}{ Narok } & UH3 & $1.3 \mathrm{~d}$ & $1.4 \mathrm{~d}$ & $25.3 \mathrm{a}$ & $0.7 \mathrm{a}$ & $0.7 \mathrm{~d}$ & $0.7 \mathrm{c}$ & $0.71 \mathrm{~b}$ \\
\hline & UH4 & $17.4 \mathrm{a}$ & $6.7 \mathrm{c}$ & $10.4 \mathrm{a}$ & $6.8 \mathrm{a}$ & $9.7 \mathrm{a}$ & $7.2 \mathrm{a}$ & $7.25 \mathrm{a}$ \\
\hline & Mean & 12.0 & 6.3 & 12.1 & 5.1 & 6.4 & 5.1 & 5.4 \\
\hline
\end{tabular}

Means followed by different letters for each Fusarium genus within the districts are significantly (p < 0.05) different; LH4: Lower highland 4, UH2: Upper highland 2; UH3: Upper highland 3; UH4: Upper highland 4; LH3: Lower highland 3; LH2: Lower highland 2; F. gram: F. graminearum; F. stil: F. stilboides; F. verti: F. verticillioides; F. hete: F. heterosporum and F.tri: F. tricinctum. 


\subsection{Contamination of Wheat Kernels with T2-Toxin}

The prevalence of T2-toxin in the kernel samples was $100 \%$ and the mean concentration varied from 9 to 14 ppb (Table 9). Samples from fields where F. poae was isolated in high frequency had a corresponding high concentration of T2-toxin. The widest variability in T2toxin concentration was in Nyandarua North district ranging from $3.5 \mathrm{ppb}$ in $\mathrm{LH} 3$ to $23.2 \mathrm{ppb}$ in $\mathrm{UH} 4$. On the other hand, the lowest variability among the various AEZ was in Narok (59\%) compared to $85 \%$ in Nyandarua North district. There were no significant $(\mathrm{p}<0.05)$ differences in T2-toxin contamination levels among the AEZ within the three districts.

\section{DISCUSSION}

Although many wheat cultivars were grown by farmers in the three diverse districts during the study period, they were all susceptible to FHB and Fusarium infection of vegetative parts. The popularity of newer released cultivars among farmers could be attributed to possession of good qualities, such as tolerance to disease, drought tolerance and high yielding capacity as compared to the older varieties [21]. Seventy percent of the farmers cul- tivated maize either side-by-side with wheat or as a rotation crop. Maize could therefore be a source of primary inoculum and contributing to the high Fusarium incidence in the three districts. Fusarium infection of wheat sown in a field with maize residue may be two to three times more severe [22]. According to Dubin et al. [23], wheat scab epidemics depend mainly on the amount of primary inoculum rather than secondary inoculum. The Fusarium spp. in the wheat debris from previous seasons can survive long in the soil due to the pathogen's saprophytic nature [24]. The reservoir for primary inoculum could be compounded by rotation of wheat crop with maize, a common practice in the three study districts.

Fusarium head blight and Fusarium infection of vegetative wheat parts was prevalent in all the agroecological zones with incidence of up to $88 \%$. A previous study in Kenya [14] showed that most wheat cultivars available are susceptible to FHB, none are immune and only a few are moderately resistant. The high FHB incidence in the current study contrasts with the findings by Riungu et al. [12] who reported low FHB incidence. The difference could be attributed to favourable weather conditions for FHB development during the 2008 cropping season.

Fusarium, Alternaria, Trichoderma, Epicoccum and

Table 9. Contamination levels of T2-toxin (ppb) in wheat kernels collected at harvest from farmers in different agro ecological zones of wheat growing districts in Kenya.

\begin{tabular}{|c|c|c|c|c|c|c|c|}
\hline \multirow{2}{*}{ District } & \multicolumn{6}{|c|}{ Field } & \multirow{2}{*}{ Mean } \\
\hline & & 1 & 2 & 3 & 4 & 5 & \\
\hline \multirow[t]{2}{*}{ Nyandarua } & LH3 & 11.0 & 6.8 & 3.5 & 13.2 & 10.9 & 9.1 \\
\hline & LH4 & 16.6 & 16.7 & 12.5 & 10.8 & 11.7 & 13.7 \\
\hline \multirow{3}{*}{ North } & UH3 & 9.5 & 12.2 & 12.2 & 16.8 & 11.1 & 12.4 \\
\hline & UH4 & 9.8 & 12.2 & 23.2 & 11.7 & 11.6 & 13.7 \\
\hline & Mean & 11.7 & 12.0 & 12.9 & 13.1 & 11.3 & 12.2 \\
\hline \multirow[t]{2}{*}{ Imenti } & LH2 & 16.2 & 18.6 & 11.1 & 10.8 & 13.5 & 14.0 \\
\hline & LH4 & 10.9 & 13.9 & 7.5 & 12.7 & 12.2 & 11.4 \\
\hline \multirow{3}{*}{ North } & $\mathrm{UH} 2$ & 16.8 & 23.0 & 8.6 & 12.5 & 11.0 & 14.4 \\
\hline & UH3 & 11.6 & 9.2 & 12.4 & 16.8 & 11.3 & 12.3 \\
\hline & Mean & 13.9 & 16.2 & 9.9 & 13.2 & 12.0 & 13.0 \\
\hline \multirow{5}{*}{ Narok } & LH4 & 13.3 & 10.8 & 15.8 & 11.2 & 18.5 & 13.9 \\
\hline & $\mathrm{UH} 2$ & 10.8 & 10.9 & 12.3 & 20.7 & 17.3 & 14.4 \\
\hline & UH3 & 11.3 & 16.1 & 11.1 & 8.4 & 10.8 & 11.6 \\
\hline & UH4 & 11.1 & 11.3 & 12.5 & 8.6 & 10.9 & 10.9 \\
\hline & Mean & 11.6 & 12.3 & 12.9 & 12.2 & 14.4 & 12.7 \\
\hline
\end{tabular}

LH4: Lower highland 4; UH2: Upper highland 2; UH3: Upper highland 3; UH4: Upper highland 4; LH3: Lower highland 3; LH2: Lower highland 2. 
Penicillium were the prevalent fungal genera in soil, stems, heads, straw and grains. The fungal spectrum concurred with the findings of recent studies carried out on wheat grain in Kenya [12,25-27]. Where wheat was highly infected by Epicoccum and Alternaria, there was a corresponding low infection level by Fusarium. Similar findings have been reported [11,12,27-29]. This indicates the possibility of antagonism among the two fungal groups. Besides Fusarium spp., Penicillium is a producer of various mycotoxins such as patulin, mycophenolic, penicilic acid, roquefortins, marcfortine $\mathrm{A}$, andrastin, gliotoxins and toxins of verruculogen/femitremorgen group [30,31]. Therefore, there is a likelihood of a wide spectrum of mycotoxins contaminating wheat in the three districts, with health implications on human and livestock who are consumers of food and feed, respectively.

Different Fusarium species were isolated in high frequency in the grains, stems, straw, soil and heads. The wide diversity was comparable to the findings of other studies in Kenya [9,11,12,27]. Fusarium head blight is caused by a complex of several Fusarium species [32, 33]. However, different Fusarium species predominate various regions $[9,34,35]$. The predominance of certain Fusarium species in a region influences the major mycotoxins contaminating wheat. Based on the spectrum of Fusarium spp. identified in this study, there is a possibility of contamination of wheat grains, grain-based foods and straw with deoxynivalenol, nivalenol, T2-toxin, HT-2 toxin, Fusarenone-X, Diacetoxyscirpenol, enniatins, fusarin, moniliformin, which have been associated with human and animal toxicoses [6,9,36,37]. Due to differences in survival strategies and mycotoxin production, the presence of different Fusarium spp. may pose challenges in managing the pathogen.

Isolation of Fusarium species from different wheat parts sampled at different growth stages emphasizes the role of debris in the pathogen cycle, disease monitoring as well as the importance of managing of the pathogen during different growth stages. All Fusarium species that infect cereals are capable of surviving saprophytically on crop debris [4,38,39]. Ascospores and conidia present in infected residues of previous crops still present in the field are splash-dispersed to wheat ears at anthesis where they act as primary inoculum for new infections [24, 40,41]. This implies that infected residues left in the field play a crucial role in the survival and spread of these economically important pathogens. The presence of straw in the soil generally leads to increased pathogen populations in soils [42]. The Fusarium inoculum in the soil and cereal residues has also been known to attack young cereal crops causing crown or root rot $[3,4,38]$. In the long run, removal of residues after harvesting as well as rotation programs with non-cereal crops is recommended to reduce inoculum levels [38]. The numerous pathogens infecting wheat could have a synergistic effect on FHB severity and result in a wide spectrum on mycotoxins. Additionally, infection of straw by Fusarium species may be a health risk of exposing livestock to Fusarium-related mycotoxins when fed on hay, fodder or where straw is used as bedding material.

All grain samples analyzed were contaminated with T2-toxin whose concentration varied from 3.5 to $23 \mathrm{ppb}$. The lowest mean T2-toxin levels (minimum $3.5 \mathrm{ppb}$ ) were detected in grain from agro-ecological zone $\mathrm{LH}_{3}$ while the highest (maximum $14.4 \mathrm{ppb}$ ) were detected in grain from $\mathrm{UH}_{2}$ and $\mathrm{UH}_{4}$ in all the three areas surveyed. A recent study [26] showed that $86 \%$ of wheat grains sampled from different agro-ecological zones in Kenya were contaminated with T2-toxin. This toxin is one the major mycotoxins produced by $F$. poae [6], the most predominant species in the three districts. Fungal metabolites including mycotoxins pose serious threats to human and animal health [43]. Type A trichothecenes such as T2-toxin, HT-2 toxin, neosolaniol and diacetoxyscirpenol are more acutely toxic than type B trichothecenes such as deoxynivalenol, fusarenone- $X$ and nivalenol $[36,44]$. T2-toxin causes outbreaks of haemorrhagic disease in domestic animals and is the causative agent of alimentary toxic aleukia. The toxin is also a teratogen and causes stillbirth, abortion and featal abnormalities. T2-toxin targets the immune system causing changes in leukocyte counts, and depression of antibody formation. Exposure to the toxin also results in skin pain, nausea, weight loss, vomiting and diarrhea. Severe poisoning results in prostration, weakness, ataxia, collapse, reduced cardiac output, shock and death [45]. Therefore, T2-toxin poses a threat to food and feed industries. More efforts including breeding for resistance, managing Fusarium spp. during different growth stages and removal of plant debris are required to reduce Fusarium infection and mycotoxin contamination. These interventions are necessary for increased yield and to reduce risk of chronic T2-toxin exposure to humans and livestock in the regions.

\section{ACKNOWLEDGEMENTS}

Financial support by the International Foundation for Science (IFS Grant C3654-2) is greatly acknowledged. We acknowledge logistical support at the study sites by the district agricultural offices of the Ministry of Agriculture.

\section{REFERENCES}

[1] Kenya Agricultural Research Institute (KARI) (1989) Current situation of wheat production in Kenya. Kenya Agricultural Research Institute, Nairobi, Kenya.

[2] Akinsanmi, O.A., Mitter, V., Simpfendorfer, S., Back- 
house, D. and Chakraborty, S. (2004) Identity and pathogenicity of Fusarium spp. isolated from wheat fields in Queensland and northern New South Wales. Australian Journal of Agricultural Research, 55, 97-107. doi:10.1071/AR03090

[3] Mudge, A.M., Dill-Macky, R., Dong, Y., Gardiner, D.M., White, R.G. and Manners, J.M. (2006) A role for the mycotoxin deoxynivalenol in stem colonisation during crown rot disease of wheat caused by Fusarium graminearum and Fusarium pseudograminearum. Physiological and Molecular Plant Pathology, 69, 73-85. doi:10.1016/j.pmpp.2007.01.003

[4] Parry, D.W., Jenkinson, P. and McLeod, L. (1995) Fusarium ear blight (scab) in small grains-A review. Plant Patholology, 44, 207-238. doi:10.1111/j.1365-3059.1995.tb02773.x

[5] Tomohiro, B. and Kazuhiro, S. (2000) Genetic analysis of resistance to Fusarium head blight caused by Fusarium graminearum in Chinese wheat cultivar Sumai 3 and the Japanese cultivar Saikai 165. Euphytica, 113, 87-99. doi:10.1023/A:1003951509797

[6] Weidenbörner, M. (2008) Mycotoxins in foodstuffs. Springer-Verlag, Berlin.

[7] Chianu, J., Ajani, N.I. and Chinua, J.N. (2008) Livelihoods and rural wealth distribution among farm households in western Kenya: Implications for rural development, poverty alleviation interventions and peace. African Journal of Agricultural Research, 3, 455-464.

[8] Food and Agriculture Organization of the United Nations (FAO) and the World Bank (2001) Summary-Farming systems and poverty: Improving farmers' livelihoods in a changing world. FAO and World Bank, Rome and Washington DC.

[9] Wagacha, J.M., Steiner, U., Dehne, H.-W., Zuehlke, S., Spiteller, M., Muthomi, J. and Oerke, E.-C. (2010) Diversity in Mycotoxins and fungal species infecting wheat in Nakuru District, Kenya. Journal of Phytopathology, 157, 527-535. doi:10.1111/j.1439-0434.2009.01653.x

[10] Verica, B.J., Igor, M.J., Tatjana, R.S., Biljana, F.A., Milutin, D.R. and Jelena, F.J. (2007) Wheat safety in relation to presence and content of deoxynivalenol. Zbornik Matice Srpske za Prirodne Nauke, 113, 17-25.

[11] Muthomi, J.W., Ndung'u, J.K., Gathumbi, J.K., Mutitu, E.W. and Wagacha, J.M. (2008) The occurrence of Fusarium species and mycotoxins in Kenyan wheat. Crop Protection, 27, 1215-1219. doi:10.1016/j.cropro.2008.03.001

[12] Riungu, G.M., Muthomi, J.W., Narla, R.D. and Gathumbi, J.K. (2008) Fusarium head blight, DON and Fusarium contamination of Wheat and Maize. Journal of Plant Pathology, 1, 13-19.

[13] Guo, X.W., Fernando, W.G.D., Bullock, P. and Sapirstein, H. (2010) Quantifying cropping practices in relation to inoculum levels of Fusarium graminearum on crop stubble. Plant Pathology, 59, 1107-1113. doi:10.1111/j.1365-3059.2010.02353.x

[14] Muthomi, J.W., Oerke, E.-C., Dehne, H.-W. and Mutitu, E.W. (2002) Susceptibility of Kenyan wheat varieties to head blight, fungal invasion and deoxynivalenol accumu- lation inoculated with Fusarium graminearum. Journal of Phytopatholology, 150, 30-36. doi:10.1046/j.1439-0434.2002.00713.x

[15] Nirenberg, H. (1981) A simplified method for identifying Fusarium species occuring in wheat. Canadian Journal of Botany, 59, 1599-1609. doi:10.1139/b81-217

[16] Nelson, P.E., Toussoun, T.A. and Marassas, W.F.O. (1983) Fusarium Species: An illustrated manual for identification. Pennsylvania State University Press, University Park, USA.

[17] Seifert, K. (1996) Fuskey-Fusarium interactive key. Agriculture and AgriFood, Canada.

[18] Leslie, J.F. and Summerell, B.A. (2006) The Fusarium laboratory manual. Blackwell Publishing, Iowa, USA. doi:10.1002/9780470278376

[19] AOAC (Association of Official Analytical Chemists) (1995) Official Methods of Analysis. 16th Edition, AOAC International, Arlington, Virginia.

[20] Gathumbi, J.K., Usleber, E. and Maertlbauer, E. (2001) Production of ultra sensitive antibodies against aflatoxin B1. Letters in Applied Microbiology, 99, 349-351. doi:10.1046/j.1472-765X.2001.00914.x

[21] Noah, E. and Waithaka, M. (2005) Grain production in Kenya. Export Processing Zones Authority, Athi River, Kenya.

[22] Teich, A.H. and Nelson, K. (1984) Survey of Fusarium head blight and possible effects of cultural practices in wheat fields in Lambton County in 1983. Canadian Plant Disease Survey, 64, 11-13.

[23] Dubin, H.J., Gilchrist, L., Reeves, J. and McNab, A. (1997) Fusarium head scab: Global status and future prospects. CIMMYT, Mexico.

[24] Sutton, J.C. (1982) Epidemiology of wheat head blight and maize ear rot caused by Fusarium graminearum. Canadian Journal of Plant Patholology, 4, 195-209. doi:10.1080/07060668209501326

[25] Muthomi, J.W., Ndungú, J. K., Chemining'wa, G.N. andWagacha, J.M. (2007) Reaction of some Kenyan wheat cultivars to head blight after inoculation with Fusarium graminearum. Asian Journal of Plant Sciences, 6, 585-591. doi:10.3923/ajps.2007.585.591

[26] Muthomi, J.W., Riungu, G.M., Ndungú, J.K., Narla, R.D., Gathumbi, J.K. and Wagacha, J.M. (2008) Head blight of wheat in Kenya and contamination of grain with mycotoxin producing Fusarium species. Journal of Plant Sciences, 3, 52-60. doi:10.3923/jps.2008.52.60

[27] Ndung'u, J.K. (2006) Fungal and mycotoxin contamination of wheat from Nakuru and Nyandarua districts of Kenya and pathogenecity of Fusarium species on wheat. M.Sc. Thesis, University of Nairobi, Kenya.

[28] Sab, V., Milles, J., Kramer, J. and Prange, A. (2007) Competitive interactions of Fusarium graminearum and Alternaria alternate in vitro in relation to deoxynivalenol and zearalenone production. International Journal of Food, Agriculture and Environment, 5, 257-261.

[29] Kosiak, B., Torp, M., Skjerve, E. and Thrane, U. (2003) The prevalence and distribution of Fusarium species in 
Norwegian cereals: A survey. Acta Agriculturae Scandinavica, 53, 168-176.

[30] Garon, D., Richard, E., Sage, L., Bouchart, V., Pottier, D. and Lebailly, P. (2006) Mycoflora and multimycotoxin detection in corn silage: Experimental study. Journal of Agricultural and Food Chemistry, 54, 3479-3484. doi:10.1021/jf060179i

[31] O’Brien, M., Nielsen, K.F., O'Kiely, P., Forristal, P.D., Fuller, H.T. and Frisvad, J.C. (2006) Mycotoxins and other secondary metabolites produced in vitro by Penicillium paneum Frisvad and Penicillium roqueforti Thom isolated from baled grass silage in Ireland. Journal of Agricultural and Food Chemistry, 54, 9268-9276. doi:10.1021/jf0621018

[32] Nicholson P., Simpson, D.R., Wilson, A.H., Chandler, E. and Thomsett, M. (2004) Detection and differentiation of trichothecenes and enniatin-producing Fusarium species on small-grain cereals. European Journal of Plant Pathology, 110, 503-514. doi:10.1023/B:EJPP.0000032390.65641.a7

[33] Vogelgsang, S., Sulyok, M., Hecker, A., Jenny, E., Krska, R., Schuhmacher, R. and Forrer, H.R. (2008) Toxigenicity and pathogenicity of Fusarium poae and Fusarium avenaceum on wheat. European Journal of Plant Pathology, 122, 265-276. doi:10.1007/s10658-008-9279-0

[34] Gunst, L., Krebs, H., Dubois, D. and Forrer, H.R. (2005) The effect of farming system, previous crop and fertilization on the incidence of ear diseases of wheat in the DOK trial 117-120. Research Conference on Organic Agriculture in the German-speaking Region, 1-4 March 2005, Kassel University Press, Kassel, Germany.

[35] Xu, X.M., Parry, D.W., Nicholson, P., Thomsett, M.A., Simpson, D., Edwards, S.G., Cooke, B.M., Doohan, F.M., Brennan, J.M., Moretti, A., Tocco, G., Mule, G., Hornok, L., Giczey, G. and Tatnell, J. (2005) Predominance and association of pathogenic fungi causing Fusarium ear blight in wheat in four European countries. European Journal of Plant Pathology, 112, 143-154. doi:10.1007/s10658-005-2446-7

[36] Desjardins, A.E. (2006) Fusarium mycotoxins. Chemistry, genetics, and biology. APS Press, St. Paul, MN, USA.

[37] Speijers, G.J.A. and Speijers, M.H.M. (2004) Combined toxic effects of mycotoxins. Toxicology Letters, 153, 91-
98. doi:10.1016/j.toxlet.2004.04.046

[38] Hogg, A.C., Johnston, R.H., Johnston, J.A., Klouser, L., Kephart, K.D. and Dyer, A.T. (2009) Monitoring Fusarium Crown rot populations in spring wheat residues using quantitative real-time Polymerase Chain Reaction. Phytopathology, 100, 49-57. doi:10.1094/PHYTO-100-1-0049

[39] Jones, R.K. (2000) Assessment of Fusarium head blight of wheat and barley in response to fungicide treatment Plant Disease, 84, 1021-1030. doi:10.1094/PDIS.2000.84.9.1021

[40] Dill-Macky, R. and Jones, R.K. (2000) The effect of previous crop residues and tillage on Fusarium head blight of wheat. Plant Disease, 84, 71-76. doi:10.1094/PDIS.2000.84.1.71

[41] Fernando, W.GD., Miller, J.D., Seaman, W.L., Seifert, K. and Paulitz, T.C. (2000) Daily and seasonal dynamics of airborne spores of Fusarium graminearum and other Fusarium species sampled over wheat plots. Canadian Journal of Botany, 78, 497-505.

[42] Bateman, G.L., Murray, G., Gutteridge, R.J. and Coskun, H. (1998) Effects of method of straw disposal and depth of cultivation on populations of Fusarium spp. in soil and on brown foot rot in continuous winter wheat. Annals of Applied Biology, 132, 35-47. doi:10.1111/j.1744-7348.1998.tb05183.x

[43] Bennett, J.W. and Klich, M. (2003) Mycotoxins. Clinical Microbiology Reviews, 16, 497-516. doi:10.1128/CMR.16.3.497-516.2003

[44] Rotter, B.A., Prelusky, D.B. and Pestka, J.J. (1996) Toxicology of deoxynivalenol (vomitoxin). Journal of Toxicology and Environmental Health, 48, 1-34. doi:10.1080/009841096161447

[45] WHO (2001) Food additives series 47, FAO food and nutrition paper 74. The 56th Meeting of the Joint FAO/ WHO Expert Committee on Food Additives (JECFA), WHO, Geneva, 557.

[46] Ministry of Agriculture and GTZ (2007) Farm management hand book of Kenya. Natural Conditions and Farm Management Information, 2, 269-276. 